\begin{tabular}{|l|l|l||}
\hline \multicolumn{2}{|c|}{ PublisherInfo } \\
\hline \hline PublisherName & $:$ & BioMed Central \\
\hline \hline PublisherLocation & $:$ & London \\
\hline \hline PublisherImprintName & $:$ & BioMed Central \\
\hline \hline
\end{tabular}

\title{
Mosquito microarrays
}

\begin{tabular}{|l|l|l||}
\hline \multicolumn{2}{|c|}{ ArticleInfo } \\
\hline \hline ArticleID & $:$ & 4512 \\
\hline \hline ArticleDOI & $:$ & $10.1186 /$ gb-spotlight-20020625-01 \\
\hline \hline ArticleCitationID & $:$ & spotlight-20020625-01 \\
\hline \hline ArticleSequenceNumber & $:$ & 178 \\
\hline \hline ArticleCategory & $:$ & Research news \\
\hline ArticleFirstPage & $:$ & 1 \\
\hline \hline ArticleLastPage & $:$ & 2 \\
\hline \hline & & RegistrationDate : 2002-6-25 \\
\hline ArticleHistory & $:$ & OnlineDate \\
\hline \hline ArticleCopyright & $:$ & BioMed Central Ltd2002-6-25 \\
\hline \hline ArticleGrants & $:$ & \\
\hline \hline ArticleContext & $:$ & 130593311 \\
\hline \hline
\end{tabular}




\section{Jonathan B Weitzman}

Email: jonathanweitzman@hotmail.com

Genomic analysis of Anopheles gambiae may provide insights into the role of the mosquito immune system in Plasmodium infection and the transmission of malaria. In the June 25 Proceedings of the

National Academy of Sciences, Dimopoulos et al. report the use of first-generation cDNA microarrays for expression profiling analysis of the mosquito defence system (Proc Natl Acad Sci USA 2001, 99:8814-8819). The microarrays contained 3840 EST clones. They used a hemocyte-like cell line, 4a-3B, that had been challenged with Gram-positive or Gram-negative bacteria or treated with hydrogen peroxide. Expression profile analysis grouped the genes into clusters related to immune or oxidativestress responses, or both. Microarray analysis of whole mosquitoes infected with bacteria or with malaria parasites revealed similarities in the gene expression changes in vivo, as well as distinct groups of genes for each response.

\section{References}

1. What's buzzing? Mosquito genomics and transgenic mosquitoes.

2. Proceedings of the National Academy of Sciences, [http://www.pnas.org]

3. Anopheles gambiae genome view, [http://www.ncbi.nlm.nih.gov:80/cgi-bin/Entrez/ map_search?chr=agambiae.inf]

This PDF file was created after publication. 